Citation: Ünal, M., Latifov, F., "High temperature effect on the strength of sand-cement plaster". Journal of Engineering Technology and Applied Sciences 2 (3) 2017 : 131-136.

\title{
HIGH TEMPERATURE EFFECT ON THE STRENGTH OF SAND-CEMENT PLASTER
}

\author{
Murat Ünal a*, Fehmi Latifov \\ a* Department of Mining Engineering, Engineering Faculty, Onsekiz Mart University, Canakkale, \\ Turkey \\ murat.unal@comu.edu.tr
}

\begin{abstract}
One of the main physical effects leading to durability problems in buildings is high temperature. This effect can cause permanent damage to structures, resulting in loss of service, life and property. Sandcement plaster is used extensively in building work as a decorative or protective coating for concrete and masonry walls. One of the important tasks of the sand-cement plaster is to protect the building elements against the high temperature which is the result of the fire. The determination of the degree of the influence of high temperatures on the sand-cement plaster is important in this respect. In this study, commonly used sand cement plaster material is used. The impact ratings of the plaster samples exposed to different temperatures were tried to be determined by measuring ultrasonic sound transmission values and flexural strengths.
\end{abstract}

Keywords: Sand-cement plaster, ultrasonic sound, flexural strength

\section{Introduction}

The purpose of the plaster is not only to correct all the joints and roughness of the roughing of the inner and outer surfaces of the walls. Most importantly, the moisture content of the building, heat and sound insulation should be arranged. It is also used as preventive and protective material against fire. Fire is a phenomenon that occurs with uncontrolled combustion of solid, liquid and gaseous substances. In a structure, it is imperative that all elements and components have to resist the fire and its effects for a certain period of time, irrespective of their position, and whether they are carriers or not. All the elements and components in the building are damaged by the high temperature caused by the fire even though they are ignited and they can cause a lot of loss of lives and property with the collapse of these buildings. The degree of damage is usually assessed by two factors. These are the 
temperature grade reached during the fire and the duration of exposure of the material to this temperature $[1,2,3]$.

The post-fire high temperature impact on buildings and structures has been noted in many studies $[1,2,4,5,6,7]$. There are also studies in the literature $[8,9,10]$ about the resistance of plaster mortars to high temperature effects. These effects can be determined by general observations, physical sampling methods and non-destructive measurement methods. Today, non-destructive measurement methods are widely used.

In this study, plaster samples were prepared according to the standards by using cement and Eğribayat sand. The degree of influence of high temperature on these specimens was determined by measuring the ultrasonic velocity values and flexural strengths of the samples subjected to different temperatures. The results showed that high temperature had a significant effect on plaster.

\section{Materials and methods}

\subsection{Materials and samples}

As a plaster aggregate, sand obtained from Eğribayat province was used. This sand is widely used in Konya. Some features of this sand are listed below [11].

- Organic material and porosity have not been observed.

- The surface of the grain is bright and conglomerates are observed in the grains.

- The amount of crusted grain is $8 \%$.

- Unit volume weight $2.66 \mathrm{gr} / \mathrm{cm}^{3}$

Portland cement (PÇ 42.5) was used as the binder material [12]. The test specimens were prepared in 40x40x160 mm dimensions (Figure 1) in accordance with TS 1481[13] and TS EN 196-1 [14] and considering the mixture ratios given in Table 1. Two groups of specimens were prepared: thin plaster $(-1 \mathrm{~mm})$ and roughcast $(-2 \mathrm{~mm})$. The samples were cured in water for 7 days.

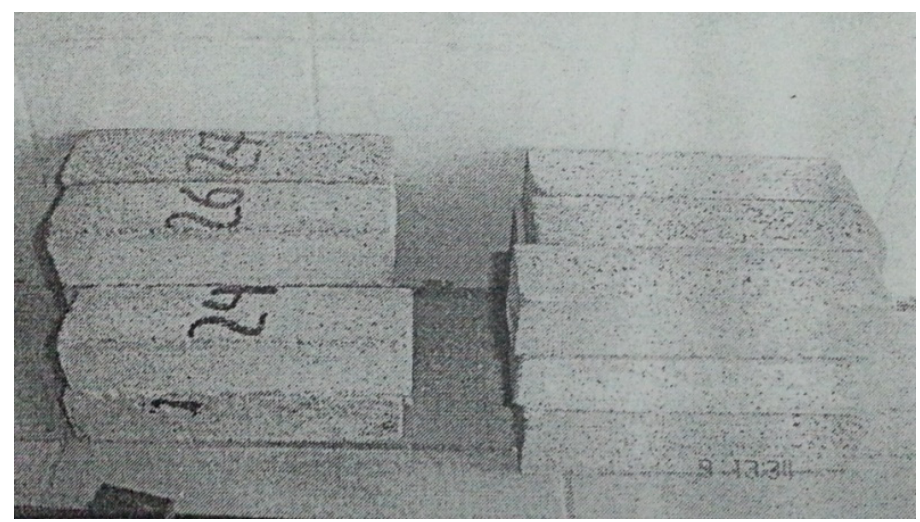

Figure 1.Test samples 
Table 1. Mixing ratios of the samples

\begin{tabular}{|c|c|c|}
\hline Material & Mixture (TS 1481) & Mixing ratio for samples \\
\hline Agregate & $1 \mathrm{~m}^{3}$ & $1.425 \mathrm{~kg}+1.365 \mathrm{~kg}$ additional \\
\hline Cement & $350-500 \mathrm{~kg}$ & $0,979 \mathrm{~kg}+0.957 \mathrm{~kg}$ additional \\
\hline Water & $140-170 \mathrm{lt}$ & $0,722 \mathrm{~kg}+0,278 \mathrm{~kg}$ additional \\
\hline
\end{tabular}

\subsection{Measuring methods}

In the fire model, an ash furnace was used. During the fire, it is assumed that the temperature lasts for an hour and rises to $900{ }^{\circ} \mathrm{C}$. For this, the samples were exposed to temperatures of $150,300,450,600,750$ and 900 degrees for an hour. The samples were allowed to cool in the furnace.

The degradation ratios of the samples due to high temperature were determined using ultrasonic wave velocity measurement and flexural strength tests. Pundit Plus instrument and $54 \mathrm{kHz}$ transducers were used for ultrasonic wave velocity measurements. The transit time of the samples was measured, and the velocity of the sample was calculated by the ratio of the transit time to the transit time. The changes in the strengths of the specimens were determined in accordance with TS EN 196-1 with the flexural strength test. At least 3 samples were used for each parameter.

\section{Results and evaluations}

Ultrasonic measurement method was used to determine the degree of damage of the sandcement plasters from high temperature without any damage. Firstly, the ultrasonic wave velocities of samples were measured before and after the samples were exposed to different temperatures and the obtained data are given in Table 2. The percentage changes due to temperature are shown in Figure 1c. The flexural strengths of the sand-cement plaster samples were examined to determine the effect of the temperature on the strength of the sand-cement plaster and the results obtained are also given in Table 2. The rate of change is shown in Figures $1 \mathrm{a}$ and $1 \mathrm{~b}$.

As shown in Table 2, as the temperature increases, ultrasonic velocity and bending strength values decrease. It has been determined that the bending strength of roughcast is higher than that of thin plaster and is more affected than temperatures of 750 degrees and above.

Table 2. Arithmetic mean of the ultrasonic velocities and flexural strength values of the samples [15].

\begin{tabular}{|c|c|c|c|c|c|}
\hline $\begin{array}{c}\text { Sample } \\
\text { No }\end{array}$ & $\begin{array}{l}\text { UVB (m/sn) } \\
\text { (for }-2 \mathrm{~mm})\end{array}$ & $\begin{array}{c}\text { Temperature } \\
\left({ }^{\circ} \mathrm{C}\right)\end{array}$ & $\begin{array}{l}\text { UVA (m/sn) } \\
\text { (for }-\mathbf{2 m m})\end{array}$ & $\begin{array}{c}\sigma\left(\mathrm{kgf} / \mathrm{cm}^{2}\right) \\
(\text { for-1 } 1 \mathrm{~mm})\end{array}$ & $\begin{array}{c}\sigma\left(\mathrm{kgf} / \mathrm{cm}^{2}\right) \\
(\text { for }-2 \mathrm{~mm})\end{array}$ \\
\hline 1 & 3371 & 0 & 3371 & 63,28 & 82,97 \\
\hline 2 & 3416,33 & 150 & 3271,333 & 58,22 & 69,75 \\
\hline 3 & 3401 & 300 & 2418,333 & 45,84 & 46,41 \\
\hline 4 & 3493,67 & 450 & 1530,667 & 27,56 & 27,56 \\
\hline 5 & 3515,67 & 600 & 1391,667 & 16,31 & 23,34 \\
\hline 6 & 3320,67 & 750 & 1025,333 & 11,25 & 10,13 \\
\hline 7 & 3360,67 & 900 & 704,3333 & 4,22 & 3,94 \\
\hline
\end{tabular}


UVB: Ultrasonic velocity before high temperature, UVA: Ultrasonic velocity after high temperature, $\sigma$ : Flexural strength

There were some visual changes occur in the sand-cement plaster due to the increase in temperature. It is known that these changes vary depending on the cement phase and aggregate types. The changes observed in the sand-cement plaster samples due to the temperature increase are summarized in Table 3.

Table 3. Observed changes due to temperature increase

\begin{tabular}{|c|c|}
\hline Temperature $\left({ }^{\circ} \mathrm{C}\right)$ & The effect on the samples \\
\hline 150 & Evaporation of water in the pores \\
\hline $150-300$ & Shrinkage, formation of capillary cracks, color pinking \\
\hline $300-600$ & $\begin{array}{l}\text { Increase in shrinkage, increase in the formation of capillary cracks, } \\
\text { darkening in color, slight spillage on the surface }\end{array}$ \\
\hline $600-900$ & $\begin{array}{l}\text { Significant loss of binding material property, surface spillage, color } \\
\text { graying }\end{array}$ \\
\hline
\end{tabular}

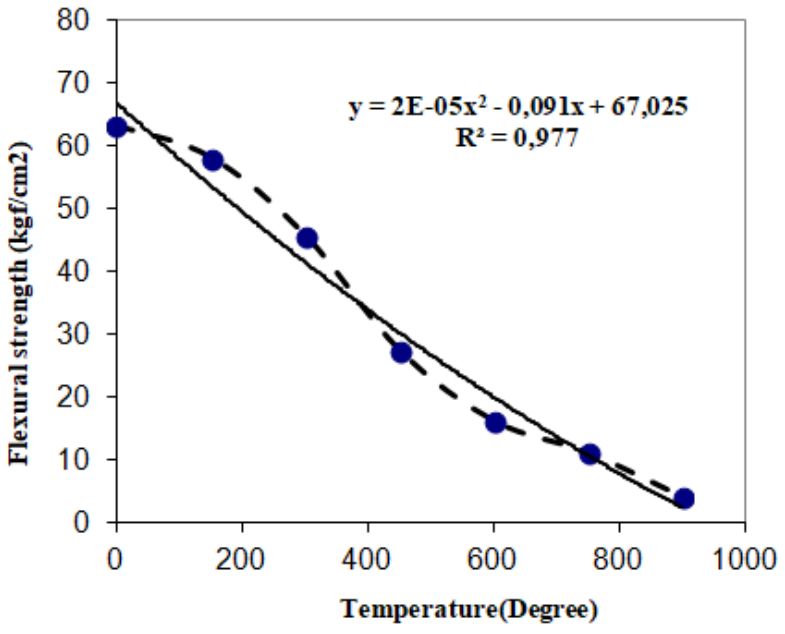

a)

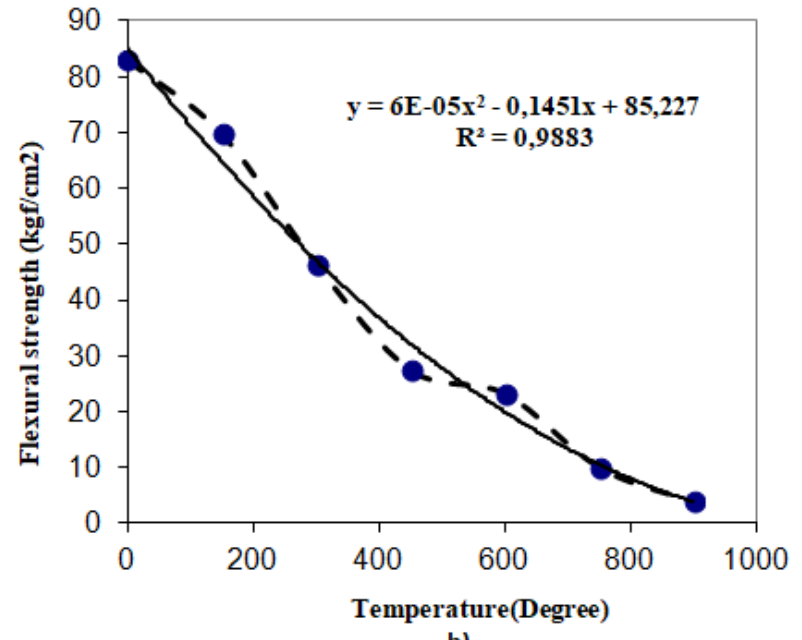

b)

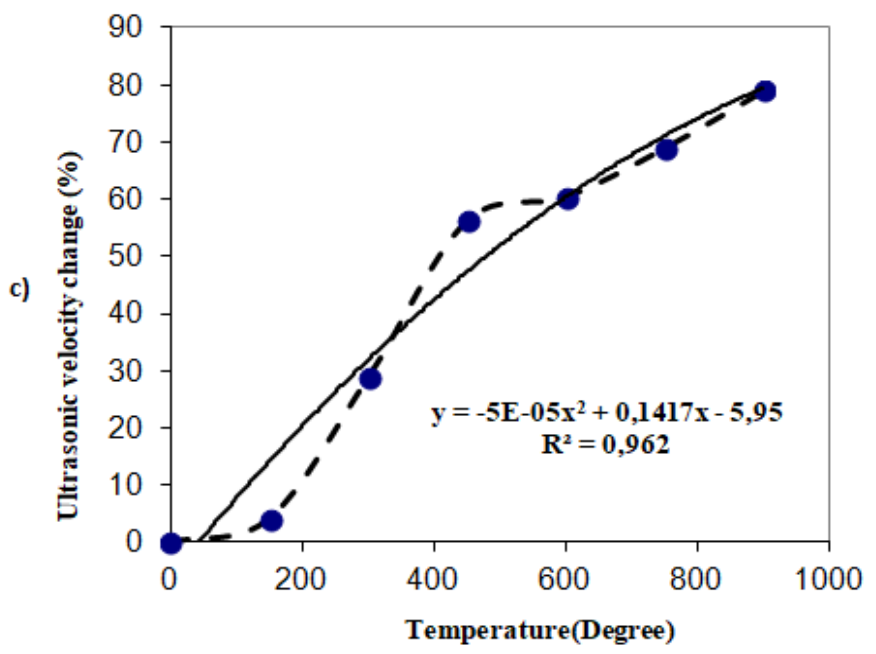

Figure 2. As the temperature rises, a) changes in flexural strength value for under $1 \mathrm{~mm}$ sieve aggregate $b$ ) changes in flexural strength value for under $2 \mathrm{~mm}$ sieve aggregate and c) the percentage change in the ultrasonic wave velocity for under $2 \mathrm{~mm}$ sieve aggregate. 
The damage that occurred at different temperatures caused the strength of the plaster to fall in large quantities. The color of the plaster samples varied depending on the degree of temperature exposure. It has been found that the color change is compatible with both the bending strength data and the ultrasonic velocity values. As shown in Figure 2, the changes at 150 degrees are caused by shrinkage formed by evaporation of free water in capillary spaces and by microfractures formed by vapor pressure. The maximum change occured 150-450 degrees. With the increase in temperature, the evaporation of water in the texture of specimens that did not evaporate under normal conditions increased the degree of damage. As shown in Figure 2, there is a nearly linear decrease in ultrasonic velocity values and flexural strengths of the samples between $150{ }^{\circ} \mathrm{C}$ and $450{ }^{\circ} \mathrm{C}$. At temperatures above 450 degrees, the change was found to increase by decreasing at equal rates. This change is thought to be caused by changes in the aggregate and cement material within the plaster. Minerals are known to have different expansion coefficients at different temperatures. For example; Quartz is a polymorphic transition at $570{ }^{\circ} \mathrm{C}$, the limestone and dolomite are transformed into $\mathrm{CaO}$ and $\mathrm{MgO}$ after $800{ }^{\circ} \mathrm{C}$ [7]. Therefore, these transformations caused damage to the sandcement plasters.

As can be seen in Figure 2, the significant change took place between $150-450{ }^{\circ} \mathrm{C}$. It is seen that the change rates between $0-150{ }^{\circ} \mathrm{C}$ and above $450{ }^{\circ} \mathrm{C}$ are almost equal. It has been determined that changes in ultrasonic wave velocity and flexural strength due to temperature increase exhibit a polynomial behavior.

The correspondence between Fig. $1 \mathrm{~b}$ and c shows the consistency of the ultrasonic method. Furthermore, the difference between Fig. $1 \mathrm{a}$ and $\mathrm{b}$ shows the effect of size differences between the particles. As the size difference increases, the strength increases. The degree of influence from the temperature above 450 degrees does not change much. This demonstrates the importance of granulometer and aggregate content.

\section{Conclusions}

The correct information about the changes in the properties of a damaged plaster due to fire can be obtained on the basis of conscious observations and determinations. The information obtained from this study is listed below.

- It has been determined that the application of the non-destructive ultrasonic measurement method may be useful in determining plaster properties that have been damaged due to fire.

- It has been determined that the relation among the temperature increase and the flexural strength and the ultrasonic velocity of the samples can be defined by the polynomial model.

- It has been observed that the physical properties of the samples are deteriorated and the flexural strength is reduced due to the increase in temperature.

- It has been determined that the aggregate grain size distribution in the plaster affects the flexural strength. The degree of influence from the temperature was found to be the same over $450^{\circ} \mathrm{C}$. 


\section{References}

[1] Baradan B., Yazıcı H. ve Ün, H. "Betonarme Yapılarda Kalıcıllk" Dokuz Eylül Üniversitesi, Mühendislik Fakültesi Yayınları, İzmir, No. 218, (2002): 281

[2] Pruter, W. F. Fire Safety with Portland Cement Plaster, Vol. 16, No. 9, (1989): 25-29.

[3] ASTM E119-16a. "Standard Test Methods for Fire Tests of Building Construction and Materials" ASTM International, West Conshohocken, PA, 2016.

[4] Lin WM, and Lin TD, Powers-Couche LJ. "Microstructures of Fire Damaged Concrete" ACI Materials Journal 93 (3) (1996): 199-205.

[5] Mehta, P.K. and Monteiro, P.J.M., Concrete, Microstructure, Properties and Materials, 154-159, Prentice-Hall, Englewood Cliffs, New Jersey, 1997.

[6] Topçu,İ.B and Demir,A. "Betonarmede yüksek sıcaklık ve yangın etkisi" TMMOB İnşaat Mühendisleri Odası Eskişehir Şubesi Ekim Bülteni, (2004): 34-37.

[7] Akman, M.S., Betonarme Yapılarda Yangın Hasarı ve Yangın Sonunda Taşıyıcılığın Belirlenmesi, (www.sika.com.tr/images/betyanginhasar.pdf), 2005.

[8] O. Y. Bayraktar, Alternatif sıva harçlarının yüksek sıcaklık etkisine dayanıklılığı, Yüksek Lisans Tezi, Gazi Üniversitesi, Ankara-Türkiye, (2012).

[9] Kaya ,T., Çerçevik A.E., Karakurt C. "Farklı Tip Sivaların Yüksek Sicaklık ve Donma Çözülme Etkisinde Mekanik Davranışı" Düzce Üniversitesi Bilim ve Teknoloji Dergisi, 4 (2016) 697-703

[10] Kaya T., Yazicioğlu S., "Kalsine Bentonit Katkılı Harçların Fiziksel ve Mekanik Özelliklerine Yüksek Sicaklık Etkisi”, BEU Journal of Science 4(2), 150-160, 2015 4(2).

[11] Somyürek, M. "Tabii agrega ocaklarına ait malzemelerin özelliklerinin tespiti ve bu malzemelerle imal edilebilecek beton sınıflarının araştırılması" Selçuk Uni, Fen Bilimleri Enstitüsü, (1985): 142.

[12] TS EN 197-1,Portland Çimentoları, TSE, Ankara Çimento-Bölüm 1: Genel Çimentolar Bileşim, Özellikler ve Uygunluk Kriterleri, Türk Standartları Enstitüsü, (2012), Ankara

[13] TS 1481 Sıva Yapım Kuralları -Bina Dış Yüzeylerinde Kullanılan, Türk Standartları Enstitüsü, (1988), Ankara.

[14] TS EN 196-1 Çimento deney metotları-Bölüm 1: Dayanım, Türk Standartları Enstitüsü, (2009), Ankara.

[15] Latifov, F.and Çelik, Ö, "Yangın etkisinin sıva betonu üzerindeki etkisinin araştırılması" Lisans Bitirme Tezi, Danışman; M.Unal, Selçuk Uni. Maden Mühendisliği Bölümü, (2005) Konya. 